\title{
Indigenous Approach to the Control of Soil Erosion among Small Scale Farmers in Asa L.G.A., Kwara State, Nigeria.
}

\begin{abstract}
Ajibade, L.T.*
Abstract

Using Asa L.G.A. as a case study, the article focuses on the understanding of the indigenous methods of controlling soil erosion in Kwara State. Participant observation, an anthropological method of data collection was employed among sixty respondents who were randomly selected from the set of aged farmers in the study area. Six different effective control measures were identified including 'Ebe ati Pooro', 'Idian', 'Agbin-Taala', 'Agbin-la', 'Agbin-Po' and one that can be likened to 'fallowing'. It was however observed that whereas farmers have more often than not practiced these control measures for intensions that are primarily different from controlling erosion, their practices coincidentally assist in averting soil erosion to considerable degree. The paper therefore draws attention to the fact that more respective attention to local knowledge and practices are necessary basis for effective and appropriate environmental policies, particularly in developing countries.
\end{abstract}

\section{KEY WORDS- Indigenous knowledge, Soil erosion, Asa, Kwara}

\section{Introduction}

1 rosion is the gradual washing surface of the earth's crust. This removal is caused by erosive agents in particular to the region where it occurs. According to Faniran and Areola (1978), erosion is the process of detachment and transportation of soil materials by the erosive agents of water, wind and ice.

In the tropics where Kwara State falls, only wind and water act as agents of erosion quite unlike that of temperate regions, which are ice/glaciers. However, water stands to be the most prominent in Kwara State except in the extreme northern end with sparse vegetation where wind is more prominent. This is not to say that it does not operate in other places, but the effects are minimal.

Soil erosion is a prominent environmental problem in Kwara State. This poses a serious threat to the people because soil is an invaluable resource in the environment. For instance, it determines agricultural potentials and provides habitat to people. Erosion occurs in various forms including splash, rill, sheet and the most devastating, gully. There is no part of the state that is free from at least one of these forms of erosion.

When the world came into being, the whole system of the earth was in conformity with one another, that is, all the individual systems were in complete harmony with one another. However, since man started carrying out various activities without taking into cognizance the effects of such activities on the environment, the harmony started breaking down with soil erosion as one of the consequences.

Since the effects of soil erosion started manifesting itself, man has become concerned about it and thus, decided to look into causes and proper possible solutions to curb the menace. In doing this, man discovered that his actions are a factor that causes soil erosion and has been proffering solutions to curbing the phenomena. However, these solutions seemed to be ineffective as the phenomena continued to occur at an alarming rate instead of being reduced. This has called for a review of the methods employed in the control of soil erosion so far.

Of course, there are several modern approaches to the control of soil erosion, which is the concern of various agricultural development activities these days. The fact remains that much of these have failed because of lack of consideration on the part of the local knowledge of the farmers who are the recipients of these innovations. Local farmers are often faced with the problem of soil erosion and they have their own control measures, which are simple and effective. In

\footnotetext{
* Department of Geography, University of Ilorin, Ilorin, Nigeria. edabijalt2001@ yahoo.com.
} 
Dogon Plateau of Mali for instance, Passogue, et. al. (1990) identified with the small farmers six different means of conserving soil. These include mounds, terraces, stone-lines, bunds or low walls, square basins and planting-holes. Hagmann and Murwiwa (1996) identified soil cover after clearing; shallow cultivation; mulching; soil bunds and ridges as the major techniques of conserving soil in southern Zimbabwe. This is perhaps what informed Millington (1984) in supporting the indigenous soil conservation techniques, which he considers as creation within the perceived environmental framework of the farmers. According to him, techniques, which do not correspond with the elements of environmental framework in this case, involving the factors perceived by farmers as influencing soil erosion, will have a low probability of adoption within the local farmers' set up.

It is against this background that this study focuses on the understanding of the indigenous methods of controlling soil erosion in Kwara State using Asa local government area as a case study. In order to achieve this, the study was designed to address the following specific objectives:

(a) To examine the causes and effects of soil erosion as understood by the farmers in the study area,

(b) To examine the farmers' ways of controlling soil erosion in the area, and;

(c) To critically appraise the effectiveness of these indigenous methods.

\section{Study Area}

The study area is Asa Local Government Area of Kwara State. It lies between latitudes $6^{0} \mathrm{~N}$ and $8^{0} \mathrm{~N}$ of the equator; and between longitudes $4^{0} \mathrm{E}$ and $8^{0} \mathrm{E}$ of the Greenwich Meridian. The study area is about 1,252 square kilometers in size with a population of 81,773 (National Population Commission, 1991).

The topography of the area can be described according to Iloeje (1972) and Okunola (1987) as an undulating plain with very broad and gentle slope, lying at an altitude of between 265 and 480 metres above sea level. The area is underlain by igneous as well as metamorphic rocks of the basement complex type and are mostly gueises, granites, schists and undifferentiated meta-sediment rocks and the over burden, which is composed mainly of clay and silt. The soils are generally alluvial in nature.

The climate and the soil of the area favour the growth of woodland and grasses (Iloeje, 1972). The study area is characterized by tropical wet and dry seasons with the monthly average temperature of $30.15^{\circ} \mathrm{C}$. The month of March has the highest average temperature of $33^{\circ} \mathrm{C}$ and August, the lowest average temperature of $27.3^{\circ} \mathrm{C}$ (FAAN, 1997). The cloud prevents direct insolation during the month of August and the green house effect of the earth helps in raising the temperature of the area in March.

The people of the area are of the Yoruba tribe, and settlements in the area include Eiye-Nkorin, Lasoju, Ote, Budo-Egba, Aiyepe, Temidire, Elebu, Alapata, Atapa, Owode, Ballah, Afon, Sara, IFoko, Alawon, Olomoda, Ojota, etc.

\section{Methodology}

The data used for this study were derived from both primary and secondary sources. While the primary data were gathered through the administration of questionnaire designed for a preliminary survey of the study area, the secondary data were gathered through the review of related literature.

There are three districts in the study area including Afon (Headquarters), Owode and Onire. In each, five settlements were randomly selected, thereby totaling fifteen settlements in all. In administering the questionnaire, stratified random sampling method was used. This is because the subject matter of this paper is an areal phenomena and not location specific. Thus, it was assumed that similar problems will be faced by farmers in the same region and that they will most likely proffer the same set of solutions. Four respondents were randomly selected from the set of aged farmers in each of the sampled settlements. A total of sixty respondents were then contacted on their farms while doing their daily job. In other words, an important anthropological method of data collection 
(participant observation) was also employed. Simple statistical tools (percentages) were used to analyze the acquired data.

\section{Results and Discussions}

\section{General Characteristics of the Respondents}

The study reveals that most of the farmers that were contacted are males with a percentage of $66.7 \%$ and $33.3 \%$ of females. This means that the males are more into farming than the females in the study area. The respondents are aged (greater than 55 years of age) and married, demonstrating the fact that the people are culturally stable. It was also believed that the aged farmers will have enough experience, which is useful for this type of study. Only about $25 \%$ of the respondents have no formal education, $50 \%$ attended Quranic schools, $8.7 \%$ attended primary schools, $4.7 \%$ have post-secondary education and $11.3 \%$ have adult education. This indicates that the people of the area are semi-literates, a fact which was assumed to have influence on their perception of land management techniques.

Furthermore, the study reveals that farming is the main occupation of the people with $56.7 \%$ of the respondents as full-time farmers and the remaining $43.3 \%$ engaging in farming and other economic activities such as transportation, trading, fishing, casual labour, etc. Distance between farms and settlements vary from less than one kilometer $(26.7 \%)$ to between one and five kilometers $(16.7 \%)$ and to above five kilometers (26.7\%). As such, most of the farmers do not have to travel long distances before getting to their farms thus, a factor, which is believed, would enhance their productivity.

The study further reveals that agricultural practice is part of the culture of the people of the area and common crops grown in the study area include yam, cassava, corn, millet, sweet potatoes, cocoyam, beans, etc. Land management techniques in the study area include shifting cultivation, crop rotation, fallowing, etc. Shifting cultivation was found to be the oldest form of land management in the area.

\section{Soil Erosion Control in the Study Area}

Most of the respondents (76.7\%) have at one time or the other noticed signs of erosion on their farmlands. Of these, $21.7 \%$ confirmed the types of erosion to be sheet erosion; $21.7 \%$ confirmed that it was just natural form of erosion (geologic erosion); $23 \%$ have witnessed wind erosion and water erosion. Majority of them have however experienced soil erosion (30.4\%) while another $4.4 \%$ could not identify the type of erosion. This clearly indicates the rampant nature of erosion in the study area.

A large percentage of respondents (73.3\%) agreed that erosion had endangered their farmland while $26.7 \%$ of them felt they had not experienced it. This group of respondents who have not experienced any form of erosion is made up of those whose farming activities are still young and thus, erosion activities have not been very rampant during their years of farming. It was gathered from the survey that this set of farmers are composed of the retired people from the urban centres such as Lagos, Ilorin, Kano, PortHarcourt, Kaduna, etc.

Apart from the fact that the farmers have witnessed various forms of soil erosion, they also have knowledge of its causes and effects. The local farmers generally believe that the major causes of soil erosion in their area include heavy rainfall, wind and their interference with the environment, especially in the area of agricultural activities. These combine together to influence vegetation cover, slope forms, climate and even soil characteristics. Smith (1962), Floyd (1965), Ofomata (1965), Faniran and Areola (1981), Hudson (1981), Lal (1981) and Ajibade (1997) have individually mentioned one or more of these as causes of soil erosion.

Soil erosion according to the farmer, may cause complete loss of agricultural land if unchecked but that the most prominent of its effects in this area are loss of crops and top soil especially, when the cultivated ridges are washed away. 
Six different control measures have been identified. Although, the farmers more often than not practice them for intensions different from controlling soil erosion. In other words, they are practices which coincidentally assist the farmers in averting soil loss. While some of these measures have local names, others can only be described alongside with the modern techniques. They include the following:

(a) Ebe ati Pooro : This is the same as 'ridging', which is the creation of narrow elevations (figure 1) or jointed mounds (figure 2) especially, for crops like maize and millets. The idea behind this according to the farmers is to soften the soil for quick germination of seed. This practice is what Adeleke and Leong (1978) refer to as slope wise contour ploughing, which further aggravate erosion as rain run-off down the furrows, which form already made channels. However, when cultivation is done at right angles to the hill slope following the contours, the flow of water is impeded and soil erosion is checked.

It is worth noting that though, the terrain of this area is averagely undulating with broad and gentle slope, there exist islands of sloppy lands where farmers do not practice slope wise cultivation.

(b) Idian : This refers to the use of wrapped weeds or grasses to cover seeded heaps and ridges (mulching). The farmers' intension in this case is to protect the seed from direct insolation from the sun especially, during the period preceding the wet season. This is particularly common in yam cultivation. The practice is also meant to protect the seed from being opened up by the splash of rain drops for birds and animals to feed on.

Indirectly therefore, the prevention of the effect the rain drops splash becomes a good measure of controlling soil erosion. This is closely related to what Dogon Plateau farmers also practiced in addition to those earlier mentioned. Here, Stalks that have been cleared away by the farmers while preparing for the new rainy season are laid on the soil in bands or even scattered to reduce soil erosion (Kassogue, el.al. 1990). This, according to Hagmann and Murwiwa (1996) is also practiced in Southern Zimbabwe. (c) Agbin-Taala/Agbin-la-Oko-Taala : This practice refers to planting of crops (especially, tree crops) around the farmlands usually to create boundaries between farms. Sometimes, they are planted to demarcate different segments of a farm. In the study area, cassava is usually planted round cultivated yam and such crops are mainly for home consumption.

There is no doubt that such practice protects the soil from being eroded as the tree crops serve as shelter to the farm. They help in holding the soil structure and protect the farm from the effects of occasional wind storm, which the farmers claim is rampant especially, in Afon district.

(d) Agbin-la : The understanding of this practice is close to crop rotation - for instance, planting of beans after maize. The farmers believe generally, that leguminous crops such as beans (eere/ewa) and melon (egusi) especially, provide nitrogen to the soil. Thus, when planted next to maize, which consume more nitrogen, will increase the fertility of the soil.

This practice allows for a wide range of crops to be grown without allowing the field to lie fallow but without depleting the soil. By growing different crops in successive years in the same field, Adeleke and Leong (1978) maintain that plant nutrients used by one crop can be replaced by another. According to them for instance, potatoes require much potash but do not exhaust nitrates. As such, they can be rotated with wheat, which uses the nitrates in the soil.

In the following year, leguminous crops can be grown to replenish nitrates since they form nitrogenous nodules on their roots, which remain in the soil when the crop is harvested. Cultivation of cereals can then follow in the forth year to take advantage of the replenished nitrates.

However, since leguminous crops spread over farmland, this practice assists in reducing the rate of erosion for it intercepts insolation and prevents direct contact between rain droplets and the soil.

(e) Agbin-Po :This refers to cultivation of more than one crop on farmland at a time 
(mixed-cropping). The purpose of doing this according to the farmers is to prevent total failure in crop, that is, if one crop fails, the other might not fail. On the other hand, when leguminous crops are combined, fertility of the soil is enhanced vis-à-vis the structure of the soil and thereby protecting the soil from being eroded.

(f) Fallowing: The sixth measure practiced by the farmers is what can be likened to 'fallowing'. This is always practiced for over-used farmlands. They allow part of their farmlands to lay 'un-used' (fallow) after a few years of intensive use. This is to give the farmlands a chance to rest so that the natural processes of vegetative decay and organic decomposition can help to restore the essential plant nutrients. The alternative to this is the use of organic manure and/or chemical fertilizers to maintain the fertility of the soil.

Fallowing assists in curbing soil erosion in the sense that it makes the structure of the soil to come together and be stronger than the force of water or wind erosion.

\section{Effectiveness of the Control Measures}

A cursory look at the identified indigenous erosion control measures reveals that they are not basically different from the modern techniques since each of them corresponds to one modern measure or the other. Examples include 'Agbin-la' which means crop rotation and 'Agbin-po meaning mixed-cropping. However, differences exist especially in the area of mode of implementation and perhaps because of the farmers' unconscious adoption of these techniques whose initial purpose are different from controlling soil erosion.

Although, majority of the farmers confirmed the occurrence of signs of soil erosion on their farmlands, the extent is quite limited especially when compared with what happens in some parts of Eastern Nigeria as reported by Ofomata (1965). This less prevalence must have resulted from the unconscious agricultural management practices embarked upon by the farmers in the study area for so long. Although, these measures have their own peculiar problems, their efficiency have been guaranteed by the farmers.

For instance, about $85 \%$ of the respondents attest to the fact that all the identified soil erosion control measures are practiced in the study area although, at different times depending on the need of individual farmers. This not withstanding, Ridging remains the most common which no farmer can do without. Where this is not practiced, scattered mounds (Figure 3) cultivated especially for crops like yam comes next. Here, an average mound is between $35 \mathrm{~cm}$ and $40 \mathrm{~cm}$ high with a base measuring $60 \mathrm{~cm}$. The size of a mound is determined by the nature of the soil, which again determines the type of crop to be grown on such soil. This method has been found effective in Mali (Kassougue, et. al 1990). According to them, it slows down the run-off of rain water, facilitates percolation, thereby reducing rate of soil erosion.

The practice of 'Idian' is however determined by the type of crop. It is often practiced in the study area for yam cultivation. "Agbin-tala" is on the prerogative of individual farmer and the available land area. 'Agbin-la' and 'Agbin-po' are also common. In fact, they are next to mound-making. This is because the farmers in the study area cultivate both for subsistence and commercial purposes and as such will not want to experience crop failure.

There is no doubt that soil erosion cannot be completely stopped but its prevalence can be checked. This is because several factors combine to cause soil erosion. According to the farmers, rainfall, wind and man's agricultural activities influence vegetation cover and slope form through cultivation. This view conforms with the observation of Wischmeier and Smith (1968) that the greatest deterrent to soil erosion is cover. Not withstanding, the fact still remains that these control measures have been effective at least, in protecting the soil of the study area from being worn. 


\section{Conclusions and Recommendations}

The study shows clearly that the peasant/traditional farmers have their own methods (though, unconsciously carried out) of controlling soil erosion thereby, exposing the relevance of indigenous knowledge system in agricultural development.

Buttressing this is the submission of Ajibade (1997) that farmers should study and understand their own environments and then adopt appropriate management measures such as the traditional farming methods, which include according to Jennings (1980) deep ploughing, crop rotation, liming, manuring, and the ploughing-in of grass crops and the avoidance of over-grazing in order to control soil erosion on their farmlands.

Documenting the farmers' knowledge is therefore imperative, and should be used hand-in-hand with modern knowledge and techniques in order to attain the best within the circumstances of our respective locations on the Nigerian, and indeed earths landscape. The modest contribution of this paper is indeed, in this direction.

\section{References}

Adeleke, B.O. and Leong, G.C. (1978), Certificate Physical and Human Geography University Press Limited, Ibadan, Nigeria.

Ajibade, L.T. (1997), Erosion, Deforestation and Industrial Pollution in Kwara State, Paper presented at the workshop organized by Kwara State Environmental Protection Agency. Ilorin, Nigeria.

Faniran, A. and Areola, O.O. (1976), Essentials of Soil Study, Heinemann, Ibadan, Nigeria.
Floyd, B.N. (1985), Soil Erosion and Deterioration in Eastern Nigeria, Nigerian Geographer Journal, Vol. 8

Hagmann, J. and Murwira, K. (1996), Indigenous Soil and Water Conservation in Southern Zimbabwe: A Study on techniques, historical Changes and Recent Developments Under Participatory Research and Extension, IIED Dryland Programme, Issue Paper No 63.

Hudson, N.W. (1981), Soil Conservation, Batford, London.

Iloeje, N.P. (1972),A New Geography of Nigeria, Longman, London.

Jennings, T. (1980), Environmental Studies: A First Course, Pitman, London.

Kassogue, A., Dolo, J. and Ponsioen, T. (1990), Traditional Soil and Water Conservation on the Dogon Plateau, Mali, IIED Dryland etwork Programme, Issue No. 23.

Lal, R. (1976), Soil Erosion Problems on Altisols in Western Nigeria and their Control, IITA Monograph, No. 1, Ibadan, Nigeria.

Millington, A.C. (1982), Soil Conservation Techniques for the Humid Tropics, Appropriate Techniques, 9(2).

National Population Commission (1991), National Census Result, Kwara State Population Statistics, Ilorin, Nigeria.

Ofomata, G.E.K. (1965), Factors of Soil Erosion in Enugu Area of Nigeria, Nigerian Geographical Journal, Vol. 8.

Okunola, Y.A. (1987), Landforms and Soil Association of Kwara State, CLUPO, KWADP, Ilorin, Nigeria.

Wischmeier, W, H. and Smith, D.D. (1965), Rainfall Energy and its Relationship to Soil Loss, Trans America Geographical Union, 39(2) 